\title{
Tissue thyroid hormone metabolism is differentially regulated during illness in mice
}

\author{
Anita Boelen', Anne H van der Spek', Flavia Bloise', Emmely M de Vries', \\ Olga V Surovtseva', Mieke van Beeren', Mariette T Ackermans², Joan Kwakkel' \\ and Eric Fliers ${ }^{1}$ \\ 1Department of Endocrinology \& Metabolism, Laboratory of Endocrinology, Academic Medical Center, \\ University of Amsterdam, Amsterdam, The Netherlands \\ 2Department of Clinical Chemistry, Laboratory of Endocrinology, Academic Medical Center, University of \\ Amsterdam, Amsterdam, The Netherlands
}

Correspondence should be addressed to A Boelen

Email

a.boelen@amc.uva.nl

\begin{abstract}
Illness induces major modifications in central and peripheral thyroid hormone (TH) metabolism, so-called nonthyroidal illness syndrome (NTIS). As a result, organ-specific changes in local TH availability occur depending on the type and severity of illness. Local TH availability is of importance for the regulation of the tissue-specific TH target genes and determined by the interplay between deiodinating enzymes, TH transport and TH receptor (TR) expression. In the present study, we evaluated changes in TH transport, deiodination and TR expression, the resulting tissue TH concentrations and the expression of TH target genes in liver and muscle in three animal models of illness. We induced (1) acute systemic inflammation by intraperitoneal injection of bacterial endotoxin (LPS), (2) chronic local inflammation by a turpentine injection in the hind limb and (3) severe pneumonia and sepsis by intranasal inoculation with Streptococcus pneumoniae. We found that all aspects of peripheral TH metabolism are differentially regulated during illness, depending on the organ studied and severity of illness. In addition, tissue TH concentrations are not equally affected by the decrease in serum $\mathrm{TH}$ concentrations. For example, the decrease in muscle TH concentrations is less severe than the decrease observed in liver. In addition, despite lower TH concentrations in muscle in all three models, muscle $\mathrm{T}_{3}$ action is differentially affected. These observations help to understand the complex nature of the nonthyroidal illness syndrome.
\end{abstract}

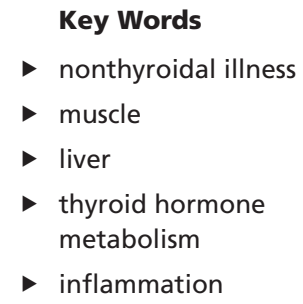

Journal of Endocrinology (2017) 233, 25-36

\section{Introduction}

During illness, thyroid hormone metabolism changes profoundly. Serum thyroid hormones decrease and the classical negative feedback loop of the hypothalamicpituitary-thyroid axis is absent. This is known as the nonthyroidal illness syndrome (NTIS). The common view is that NTIS results in an overall downregulation of metabolism via low serum $\mathrm{T}_{3}$ concentrations to save energy. However, recent studies have shown that NTIS comprises a variety of changes in transcriptional and translational activity of genes involved in local thyroid hormone metabolism ranging from inhibition to activation. These peripheral changes vary per tissue as

Published by Bioscientifica Ltd 
well as per type and severity of illness ultimately resulting in specific changes in local thyroid hormone metabolism (Boelen et al. 2011).

Local thyroid hormone concentrations in peripheral tissues depend not only on serum thyroid hormone concentrations but also on thyroid hormone transport into the target cell and the activity of TH-converting enzymes. Among the most important, thyroid hormone transporters are MCT8 and MCT10. MCT8 transports both $\mathrm{T}_{4}$ and $\mathrm{T}_{3}$ and is expressed in liver, muscle, kidney and in many brain areas (Alkemade et al. 2005, Heuer et al. 2005), whereas MCT10 preferentially transports $\mathrm{T}_{3}$ instead of $\mathrm{T}_{4}$ and is expressed in kidney, liver and muscle (Visser et al. 2011). Once transported into the cell, thyroid hormones can be metabolised by outer or inner ring deiodination through the iodothyronine deiodinases, a selenocysteinecontaining enzyme family consisting of three types: type 1 (D1), 2 (D2) and type 3 (D3) (Kohrle 2000). D1 is localised in the plasma membrane and is able to deiodinate the inner and outer ring of $\mathrm{T}_{4}$ as well as the outer ring of $\mathrm{rT}_{3}$. $\mathrm{D} 2$ is localised in the endoplasmic reticulum and deiodinates $\mathrm{T}_{4}$ into the biologically active $\mathrm{T}_{3}$. D2 is the main enzyme involved in the production of tissue $\mathrm{T}_{3}$ (Burmeister et al. 1997). D3 is localised in the plasma membrane and is the major thyroid hormone-inactivating enzyme, as it catalyses inner ring deiodination of both $\mathrm{T}_{4}$ and $\mathrm{T}_{3}$, exclusively resulting in the production of biologically inactive $\mathrm{rT}_{3}$ and $\mathrm{rT}_{2}$ (Gereben et al. 2008). Currently, tissue thyroid hormone concentrations are thought to be determined by the balance between deiodinases present in the tissue rather than by serum TH concentrations alone.

$\mathrm{T}_{3}$ binds to thyroid hormone receptors which mediate gene transcription. Two thyroid hormone receptor genes have been described, Thra and Thrb. Through alternative splicing and alternative promoter usage many isoforms are formed, resulting in classical ligand binding nuclear receptors, non-ligand binding nuclear receptors, mitochondrial isoforms and truncated $\Delta$-isoforms (Bassett et al. 2003). From the Thra gene the classical, ligand binding nuclear receptor TR $\alpha 1$ is transcribed. Two classical, ligand binding nuclear receptors isoforms are derived from the Thrb gene, TR $\beta 1$ and TR $\beta 2$. The TR $\alpha 1$ and TR $\beta 1$ are important in regulating thyroid hormone target genes in peripheral tissues and are differentially expressed between organs (Brent 2000).

During illness, all aspects of thyroid hormone metabolism are changed resulting in different bioavailability and action of thyroid hormone in peripheral tissues. The aim of the present study is to present an overview of the changes in liver and muscle thyroid hormone metabolism (characterised by Slc16A2 (MCT8), Slc16A10 (MCT10), Dio1, Dio2, Dio3, Thra and Thrb expression) observed during a variety of illnesses. As changes in local thyroid hormone metabolism may lead to altered tissue $\mathrm{TH}$ concentrations, we also determined hepatic and muscle $T_{3}$ and $T_{4}$ tissue concentrations. Thyroid hormone action was evaluated by measuring specific $\mathrm{T}_{3}$-responsive genes in liver and muscle. Three different NTIS models that differ in timing and severity were used: acute inflammation, chronic inflammation and bacterial sepsis. All these models represent true forms of NTIS; low serum $\mathrm{T}_{3}$ and $\mathrm{T}_{4}$ concentrations accompanied by a downregulation of the central HPT axis (Boelen et al. 2011).

\section{Materials and methods}

\section{Animal experiments}

We used three NTIS models to study liver and muscle thyroid hormone metabolism: acute inflammation, chronic inflammation and bacterial sepsis.

Acute inflammation was induced in female C57B16 mice (Harlan Sprague-Dawley, Horst, The Netherlands, 6-12 weeks of age, $n=6$ per group) by an intraperitoneal (i.p.) injection of $200 \mu \mathrm{g}$ LPS (Lipopolysaccharide, E. coli O127:B8; Sigma) diluted in $0.5 \mathrm{~mL}$ saline as described previously (Boelen et al. 2004). A separate control group was included for each time point to correct for the effect of diurnal variation. The experiment started at 09:00 h.

Chronic inflammation was induced in female C57B16 mice (Harlan Sprague-Dawley, Horst, The Netherlands, 6-12 weeks of age, $n=6$ per group) by a s.c. injection of $100 \mu \mathrm{L}$ steam-distilled turpentine in each hindlimb as described before (Boelen et al. 2005). Control mice received $100 \mu \mathrm{L}$ saline in each hindlimb, and the experiment started at 09:00 $\mathrm{h}$.

Bacterial sepsis was induced in female C57B16 mice (Harlan Sprague-Dawley, Horst, The Netherlands, 6-12 weeks of age, $n=6$ per group) by intranasal (i.n.) inoculation of $S$. pneumoniae serotype 3 (American Type Culture Collection, Manassas, VA, USA) (Kwakkel et al. 2009). Briefly, S. pneumoniae were grown in Todd-Hewitt broth (Difco, Detroit, MI, USA) at $37^{\circ} \mathrm{C}$, harvested at mid-logarithmic phase and washed twice in sterile saline. Bacteria were then resuspended in sterile saline. 
Mice were lightly anaesthetised, and $50 \mu \mathrm{L}$ of saline containing $5 \times 10^{4}$ colony forming units was inoculated intranasally (i.n.). Control mice received $50 \mu \mathrm{L}$ sterile saline i.n. without bacteria.

At the time points 0,8 and $24 \mathrm{~h}$ after LPS (acute model, serum TH concentrations are decreased at 8 and $24 \mathrm{~h}$ ), at $0,24,48$ and $120 \mathrm{~h}$ after turpentine injection (chronic model, serum TH concentrations are decreased at these time points) and $48 \mathrm{~h}$ after inoculation of S. pneumonia (lethal model, end-stage illness at $48 \mathrm{~h}$ ), six mice per group were anaesthetised with isoflurane, and blood was taken by cardiac puncture. Subsequently, mice were killed by cervical dislocation. Liver and muscle tissue were obtained and immediately stored in liquid nitrogen. All studies were approved by the local animal welfare committee.

\section{Tissue RNA isolation and qPCR}

Liver and muscle mRNA from S. pneumoniae-infected mice and matching controls was isolated using the Magna Pure LC mRNA tissue kit (Roche Molecular Biochemicals, Mannheim, Germany) according to the protocol. Muscle and liver RNA from the LPS and turpentine-injected mice and matching controls was isolated using the TRIzol Reagent (Invitrogen) and Macherey Nagel kit (Macherey Nagel, Düren, DE, USA) according to manufacturer's protocol. RNA yield was measured using the NanoDrop (NanoDrop, Wilmington, DE, USA) to be able to perform the cDNA synthesis with equal RNA input. cDNA synthesis was performed using the First Strand cDNA Synthesis Kit (AMV) for RT-PCR with oligo d(T) primers (Roche Molecular Biochemicals). Real-time PCR was performed using the Lightcycler480 (Roche Molecular Biochemicals) and SensiFAST SYBR No-ROX Kit (Bioline, London, UK). Primer pairs for mouse hypoxanthine phosphoribosyl transferase (Hprt), cyclophilin B, ubiquitin C, myogenin (Myog), Dio1, Dio2, Dio3, Thra1 and Thrb1 have been previously described (Bloise et al. 2016, Boelen et al. 2004, Kwakkel et al. 2010, Sjogren et al. 2007). In addition, we designed the following primer pairs for mouse: Slc16A2 (MCT8): forward primer 5'-GGGGCCCTGTCAGGAGGCAA-3', reverse primer 5'-TTTCCACAG TGGGCGTGGGC-3', annealing temperature $70^{\circ} \mathrm{C}$, Slc16A10 (MCT10): forward primer 5'-TGATTCCCCTGTGCAGCGCC-3', reverse primer 5'-CCACGTCGTAGGTGCCCAGC-3', annealing temperature $65^{\circ} \mathrm{C}, 3^{\prime}$, malic enzyme (Me1): forward primer 5'-GAAAGAGGTGTTTGCCCATGA-3', reverse primer:
5'AAT TGC AGC AAC TCC TAT GAG G-3', annealing temperature $65^{\circ} \mathrm{C}$. Quantification was performed using the LinReg software (Ruijter et al. 2009). The mean of the efficiency was calculated for each assay, and samples that deviated more than 0.05 of the efficiency mean value were excluded from the analysis ( $0-5 \%)$. Calculated values were normalised using the geometric mean of the reference genes cyclophilin-B, ubiquitin-C and HPRT.

\section{Liver deiodinase activities}

Deiodinase type 1 and type 3 activity was measured as previously described (Kwakkel et al. 2010, van Zeijl et al. 2014). Tissue was homogenised on ice in PED50 buffer $(0.1 \mathrm{M}$ sodium phosphate, $2 \mathrm{mM}$ EDTA $\mathrm{pH} 7.2,50 \mathrm{mM}$ dithiothreitol (DTT)) using a Polytron (Kinematica, Luzern, Switzerland). Homogenates were snap-frozen and stored at $-80^{\circ} \mathrm{C}$ until use. Protein concentration was measured with the Bio-Rad protein assay using bovine serum albumin (BSA) as the standard following the manufacturer's instructions (Bio-Rad Laboratories). After deiodinase and tissue-specific incubations, reactions were stopped by adding ice-cold ethanol. After centrifugation and addition of $0.02 \mathrm{M}$ ammonium acetate $(\mathrm{pH} 4)$, the mixture was applied to $4.6 \times 250 \mathrm{~mm}$ Symmetry C18 column connected to a Waters HPLC system (Model 600E pump, Model 717 WISP autosampler, Waters, Etten-Leur, The Netherlands). The activity in the eluate was measured online using a Radiomatic 150 TR flow scintillation analyser (Perkin Elmer).

Liver D1 activity was measured in duplicate, using $75 \mu \mathrm{L}$ 100-500 times diluted homogenate incubated for $30 \mathrm{~min}$ at $37^{\circ} \mathrm{C}$ in a final volume of $0.15 \mathrm{~mL}$ with $0.1 \mu \mathrm{M}$ $\mathrm{rT}_{3}$ and with the addition of approximately $1 \times 10^{5} \mathrm{cpm}$ $\left(3,3^{\prime}, 5^{\prime}-125 \mathrm{I}^{-1} \mathrm{rT}_{3}\right.$ in PED10 (0.1 M sodium phosphate, $2 \mathrm{mM}$ EDTA pH 7.2, $10 \mathrm{mM}$ DTT). One sample of each group was incubated in the presence of $500 \mu \mathrm{M}$ PTU to inhibit D1 activity representing a tissue blank. D1 activity was calculated by subtracting the activity measured in the tissue blank from the activity measured without PTU and expressed as pmol $3,3^{\prime} \mathrm{T}_{2}$ generated per minute per mg protein.

Liver D3 activity was measured in duplicate, using $75 \mu \mathrm{L}$ undiluted homogenate incubated for 2 hat $37^{\circ} \mathrm{C}$ in a final volume of $0.15 \mathrm{~mL}$ with $1 \mathrm{nM} \mathrm{T}_{3}$ or $500 \mathrm{nM} \mathrm{T}_{3}$ with the addition of approximately $2 * 10^{5} \mathrm{cpm}(3,3,5-125 \mathrm{I})$ $\mathrm{T}_{3}$ in PE buffer. For each group, we included one sample with $500 \mathrm{nM} \mathrm{T}_{3}$ to saturate $\mathrm{D} 3$, the activity measured with the incubation with $1 \mathrm{nM} \mathrm{T} \mathrm{T}_{3}$ minus the incubation 
with $500 \mathrm{nM} \mathrm{T}_{3}$ represents true D3 activity. D3 activity was expressed as fmol generated $3,3^{\prime} \mathrm{T}_{2}$ per minute per mg tissue.

\section{Serum thyroid hormone levels}

Serum $\mathrm{T}_{3}$ and $\mathrm{T}_{4}$ were measured with in-house RIA's (Wiersinga \& Chopra 1982). All samples from one experiment were measured within the same assay (intraassay variation $\mathrm{T}_{3}: 3.6 \%$ and $\mathrm{T}_{4}: 6.6 \%$ ).

\section{Tissue thyroid hormone levels}

Liver and muscle $\mathrm{T}_{3}$ and $\mathrm{T}_{4}$ concentrations were determined in 20-30 mg frozen tissue with an LC-MS/ MS method as described before (de Vries et al. 2014) but adapted for muscle tissue. Briefly, frozen skeletal muscle tissue was added to a polypropylene $2 \mathrm{~mL}$ tube containing $150 \mathrm{mg}$ zirconia beads, $50 \mu \mathrm{L}$ PBS and $20 \mu \mathrm{L}{ }^{13} \mathrm{C}_{6}$-labelled internal standards on ice. Samples were homogenised for $60 \mathrm{~s}$ at $3500 \mathrm{~g}$ using a Magna Lyser (Roche Molecular Biochemicals). Subsequently, $500 \mu \mathrm{L} \mathrm{MeOH}$ was added, samples were mixed on a vortex, homogenised again $(60 \mathrm{~s}, 3500 \mathrm{~g})$ and transferred to $5 \mathrm{~mL}$ glass tubes. The polypropylene tubes were rinsed with $500 \mu \mathrm{L}$ $\mathrm{MeOH}$, which was added to the homogenate. Ratio of volume aqueous compounds (tissue $(\mathrm{mg})+$ volume PBS $(\mathrm{mL})+$ volume IS $(\mathrm{mL})$ ) to $\mathrm{MeOH}$ (total volume) is $1: 10$. Chloroform $(2 \mathrm{~mL})$ was then added in twice the volume methanol. Samples were mixed on a vortex for $15 \mathrm{~s}$. The extraction was carried out in two steps, interspaced with centrifugations for $10 \mathrm{~min}$ at $2000 \mathrm{~g}$. In the second step, a mixture of $1 \mathrm{~mL}$ chloroform-methanol (2:1) was added to the pellet. The final volume of the extract was about 40 times the weight of the tissue plus the volume of the internal standard plus the volume of PBS, as described by Reyns and coworkers (Reyns et al. 2002). The chloroform-methanol extract was transferred to glass tubes for back-extraction of the iodothyronines into an aqueous phase with a calculated amount of $0.05 \% \mathrm{CaCl}_{2}$ (de Vries et al. 2015) followed by a second extraction with pure upper phase (chloroform:methanol:0.05\% $\mathrm{CaCl}_{2}$ 3:49:48). The iodothyronines were measured with reversed phase chromatography (Waters $\mathrm{BEH}$ C18 column: $130 \AA, 1.7 \mu \mathrm{m}, 2.1 \mathrm{~mm} \times 50 \mathrm{~mm}$ ) on an Acquity UPLC-Xevo TQ-S tandem mass spectrometer system (Waters, Milford, MA, USA). Mobile phase A was acetonitrile: $\mathrm{H}_{2} \mathrm{O}$ :acetic acid 5:95:0.1, mobile phase $B$ was acetonitrile: $\mathrm{H}_{2} \mathrm{O}$ :acetic acid 95:5:0.1. A gradient was applied with initial percentage B of $10 \%$, which was increased linearly after $2.7 \mathrm{~min}$ to $40 \%$ in $5.6 \mathrm{~min}$. Total runtime was $12 \mathrm{~min}$. Thyroid hormones and internal standards were quantified using specific MRM transitions as described previously (Ackermans et al. 2011). All aspects of system operation and data acquisition were controlled using MassLynx, version 4.1 software with automated data processing using the TargetLynx Application Manager (Waters). The additional PBS step did not affect extraction efficiency; the recoveries of ${ }^{13} \mathrm{C}_{6}$-labelled $\mathrm{T}_{3}, \mathrm{~T}_{4}$ and $\mathrm{rT}_{3}$ extracted from liver with and without the additional PBS step did not differ.

\section{Statistical analysis}

Normal distribution of the data was tested using the Shapiro-Wilk test. Statistical significance between acute/ chronic inflammation and control group was evaluated using two-way ANOVA with two grouping factors (time and treatment). When not normally distributed, data were ranked before performing ANOVA. $P$ values in the figures represent the significant effect of the treatment. To test pair-wise comparisons, ANOVA was followed by Tukey's post hoc test. Symbols in the figures represent the pair-wise $P$ values. $P$ values $<0.05$ were considered statistically significant. All tests were performed using GraphPad Prism 6 (GraphPad Software).

\section{Results}

\section{Illness-induced alterations in serum thyroid hormone concentrations}

Serum thyroid hormone concentrations were evaluated in three NTIS animal models; acute inflammation (induced by LPS), chronic inflammation (induced by turpentine injection) and $S$. pneumonia-induced bacterial sepsis. All three models differ in timing and severity; both the acute and chronic inflammation models are non-lethal, whereas bacterial sepsis is a lethal model. All three stimuli resulted in decreased serum $\mathrm{T}_{3}$ and $\mathrm{T}_{4}$ concentrations within the timeframe of the experiment and can therefore be viewed as NTIS. The changes induced however differ between the models; serum $\mathrm{T}_{3}$ decreased markedly during acute inflammation and the early phase of chronic inflammation, whereas end-stage bacterial sepsis only marginally decreased serum $\mathrm{T}_{3}$ concentrations (Fig. 1). 


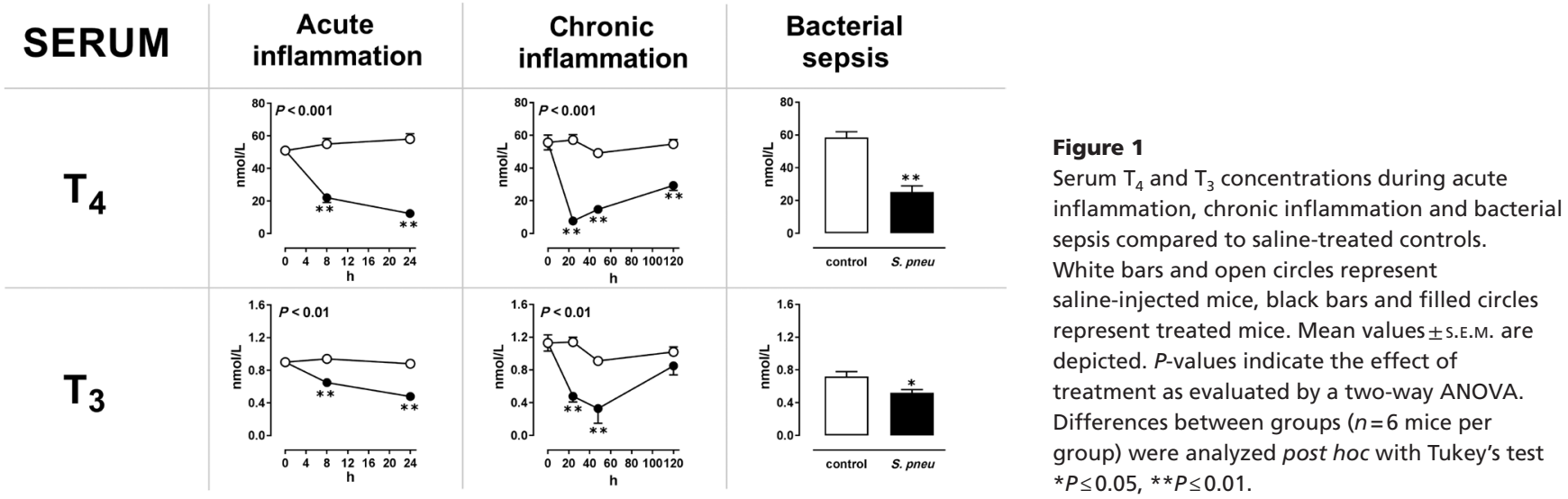

\section{Illness-induced alterations in liver thyroid hormone metabolism}

In the present study, we evaluated the components of local thyroid hormone metabolism such as $\mathrm{TH}$ transporters (MCT8 (Slc16A2) and MCT10 (Slc16A10)), deiodinases and Thrb1 (the main TR in liver) mRNA expression. Local thyroid hormone availability was determined by measuring tissue $\mathrm{T}_{3}$ and $\mathrm{T}_{4}$ concentrations. Thyroid hormone action was established by measuring mRNA expression of malic enzyme (Me1), a liver-specific $\mathrm{T}_{3}$ target gene.

LPS administration resulted in a marked decrease of liver Slc16A2 $\left(P_{\text {ANOvA }}<0.001\right)$ and Slc16A10 mRNA $\left(P_{\text {ANOvA }}<0.001\right)$ within $24 \mathrm{~h}$. Liver Dio1 and Dio3 mRNA expression (both $P_{\text {ANOVA }}<0.001$ ) was also markedly decreased within $24 \mathrm{~h}$ (data not shown). Liver D1 $\left(P_{\text {ANOva }}\right.$ $<0.001)$ and D3 activity $\left(P_{\text {ANOVA }}<0.001\right)$, liver $\mathrm{T}_{4}\left(P_{\text {ANOvA }}\right.$ $<0.001)$ and $\mathrm{T}_{3}$ concentrations $\left(P_{\mathrm{ANOVA}}<0.001\right)$ and $T h r b 1$ mRNA expression $\left(P_{\text {ANOVA }}<0.001\right)$ significantly decreased within $24 \mathrm{~h}$ after LPS compared to those in controls. Liver Me1 mRNA expression $\left(P_{\text {ANOVA }}<0.001\right)$, a positively regulated liver $\mathrm{T}_{3}$ target gene, also decreased, which is in agreement with reduced $\mathrm{T}_{3}$ action.

Turpentine administration, a model for chronic inflammation, resulted in decreased liver Slc16A2 mRNA expression $\left(P_{\text {ANOVA }}<0.001\right)$ within $24 \mathrm{~h}$, whereas Slc16A10 mRNA expression increased significantly within $48 \mathrm{~h}$ and returned to baseline after $120 \mathrm{~h}\left(P_{\text {ANOVA }}<0.01\right)$. In contrast, liver $\mathrm{T}_{4}$ concentrations decreased markedly within $48 \mathrm{~h}\left(P_{\text {ANOvA }}<0.001\right)$ and returned to baseline after $120 \mathrm{~h}$. Liver D1 activity $\left(P_{\text {ANOvA }}<0.01\right)$ and Dio3 mRNA expression (data not shown) and D3 activity (both $P_{\text {ANOvA }}<0.001$ ) decreased after turpentine injection and remained low compared to those of controls. Liver Dio1 mRNA expression (data not shown, $P_{\text {interaction }}<0.01$ ) decreased at $48 \mathrm{~h}$ but restored to control expression at
$120 \mathrm{~h}$. Liver $\mathrm{T}_{3}$ concentrations were lower at the beginning of the inflammatory response but were restored to control concentrations after $120 \mathrm{~h}\left(P_{\text {ANOVA }}<0.001\right)$. Liver Thrb1 mRNA expression did not differ between chronic inflammation and control, whereas liver Me1 mRNA expression decreased $\left(P_{\text {ANOvA }}<0.001\right)$ in line with the reduced liver $T_{3}$ concentrations indicating reduced $T_{3}$ action at the early phase of chronic inflammation.

Bacterial sepsis resulted in decreased liver Slc16A2 mRNA expression after $48 \mathrm{~h}$, whereas Slc16A10 and Thrb1 did not change. Liver $\mathrm{T}_{4}$ concentrations were markedly lower compared to those of controls. Surprisingly, liver D1 activity did not change despite significantly decreased Dio1 mRNA expression (data not shown), whereas liver Dio3 mRNA expression (data not shown) and D3 activity decreased. The net result was decreased hepatic $\mathrm{T}_{3}$ concentrations and Me1 mRNA expression indicating reduced $\mathrm{T}_{3}$ action in the liver during end-stage lethal bacterial sepsis.

In summary, acute inflammation lowered hepatic $\mathrm{TH}$ transport, hepatic $\mathrm{T}_{3}$ and $\mathrm{T}_{4}$ concentrations and $\mathrm{TH}$ action, whereas liver thyroid hormone metabolism was differentially affected during chronic inflammation. Lethal bacterial sepsis affected hepatic TH transport only marginally but lead to a marked reduction in liver D3 activity and hepatic TH concentrations and action (Fig. 2).

\section{Illness-induced alteration in muscle thyroid hormone metabolism}

In the present study, we evaluated muscle thyroid hormone metabolism by measuring the TH transporters MCT8 (Slc16A2) and MCT10 (Slc16A10), Dio2 and Dio3 mRNA expression, Thra1 (the main TR in muscle) mRNA expression and muscle $\mathrm{T}_{3}$ and $\mathrm{T}_{4}$ concentrations in three NTIS models. We also measured muscle myogenin (Myog)

Published by Bioscientifica Ltd. 


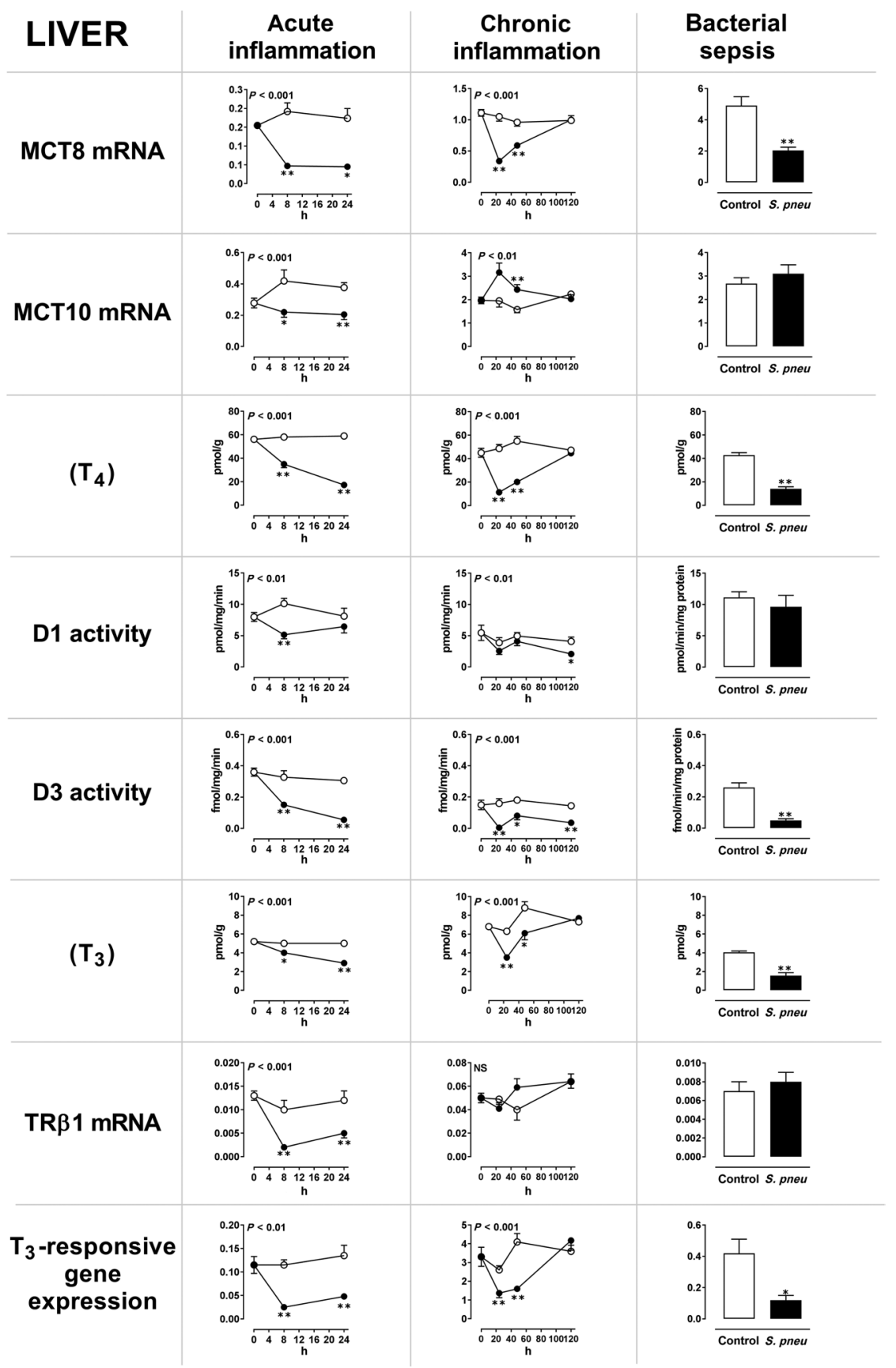

Figure 2

Relative expression of S/c16A2 (MCT8), Sc/16A10 (MCT10), Thrb1 and Me mRNA, $\mathrm{T}_{3}$ and $\mathrm{T}_{4}$ concentrations and D1 and D3 activity in the liver of mice during acute inflammation, chronic inflammation and bacterial sepsis compared to saline-treated controls. White bars and open circles represent saline injected mice, black bars and filled circles represent treated mice. Mean values \pm S.E.M. are depicted. $P$ values indicate the effect of treatment as evaluated by a two-way ANOVA. Differences between groups ( $n=6$ mice per group) were analyzed post hoc with Tukey's test $* P \leq 0.05, * * P \leq 0.01$.
mRNA expression, a $T_{3}$ target gene as a representative reflection of $\mathrm{TH}$ action.

Muscle Slc16A2 mRNA did not change after LPS administration, whereas Slc16A10 mRNA decreased $24 \mathrm{~h}$ after LPS $\left(P_{\text {ANOVA }}<0.05\right)$. LPS induced a rapid increase in Dio2 mRNA expression $\left(P_{\text {interaction }}<0.05\right)$ and a decrease in Dio3 mRNA expression $\left(P_{\text {interaction }}<0.05\right)$. Muscle $\mathrm{T}_{3}$ and $\mathrm{T}_{4}$ concentrations were lower at $24 \mathrm{~h}$ after LPS administration $\left(P_{\text {ANOVA }}<0.05\right)$, whereas Thra1 mRNA did not change. Muscle Myog mRNA expression was lower in LPS-treated mice at $24 \mathrm{~h}$ compared to that in control mice, which is in agreement with the lower muscle $\mathrm{T}_{3}$ concentrations at $24 \mathrm{~h}$.

In contrast to acute inflammation, turpentine administration did not result in significant changes in muscle Slc16A2 and Slc16A10 mRNA expression. Muscle Dio2 mRNA expression changed significantly $\left(P_{\text {interaction }}\right.$ $<0.05)$ and Dio3 mRNA expression decreased markedly after $48 \mathrm{~h} \quad\left(P_{\text {ANOVA }}<0.05\right)$. Muscle $\mathrm{T}_{4}\left(P_{\text {ANOVA }}<0.001\right)$ and $\mathrm{T}_{3}$ concentrations $\left(P_{\mathrm{ANOVA}}<0.01\right)$ and Thra1 mRNA expression $\left(P_{\text {ANOVA }}<0.001\right)$ decreased during early chronic inflammation. In contrast, muscle Myog expression, a

Published by Bioscientifica Ltd. 
$\mathrm{T}_{3}$ target gene, was higher in turpentine-treated mice compared to that in controls suggesting increased $\mathrm{T}_{3}$ action.

Sepsis resulted in decreased muscle Slc16A2 and Slc16A10 mRNA expression. We have shown before that lethal bacterial sepsis resulted in decreased muscle Dio2 mRNA expression (Kwakkel et al. 2009), whereas Dio3 mRNA did not change. Muscle $\mathrm{T}_{3}$ and $\mathrm{T}_{4}$ levels and Thra1 mRNA expression were markedly lower $48 \mathrm{~h}$ after the onset of bacterial sepsis compared to those of control mice. However, muscle Myog mRNA expression did not differ compared to control mice suggesting unchanged $\mathrm{TH}$ action in muscle at end-stage bacterial sepsis.

In summary, muscle thyroid hormone metabolism is differentially affected during illness. Acute inflammation and bacterial sepsis lowered $\mathrm{TH}$ transport into the cell, whereas chronic inflammation did not result in altered transporter expression. Muscle TH concentrations showed a small decrease during all types of NTIS only paralleled by decreased TH action during acute illness (Fig. 3).

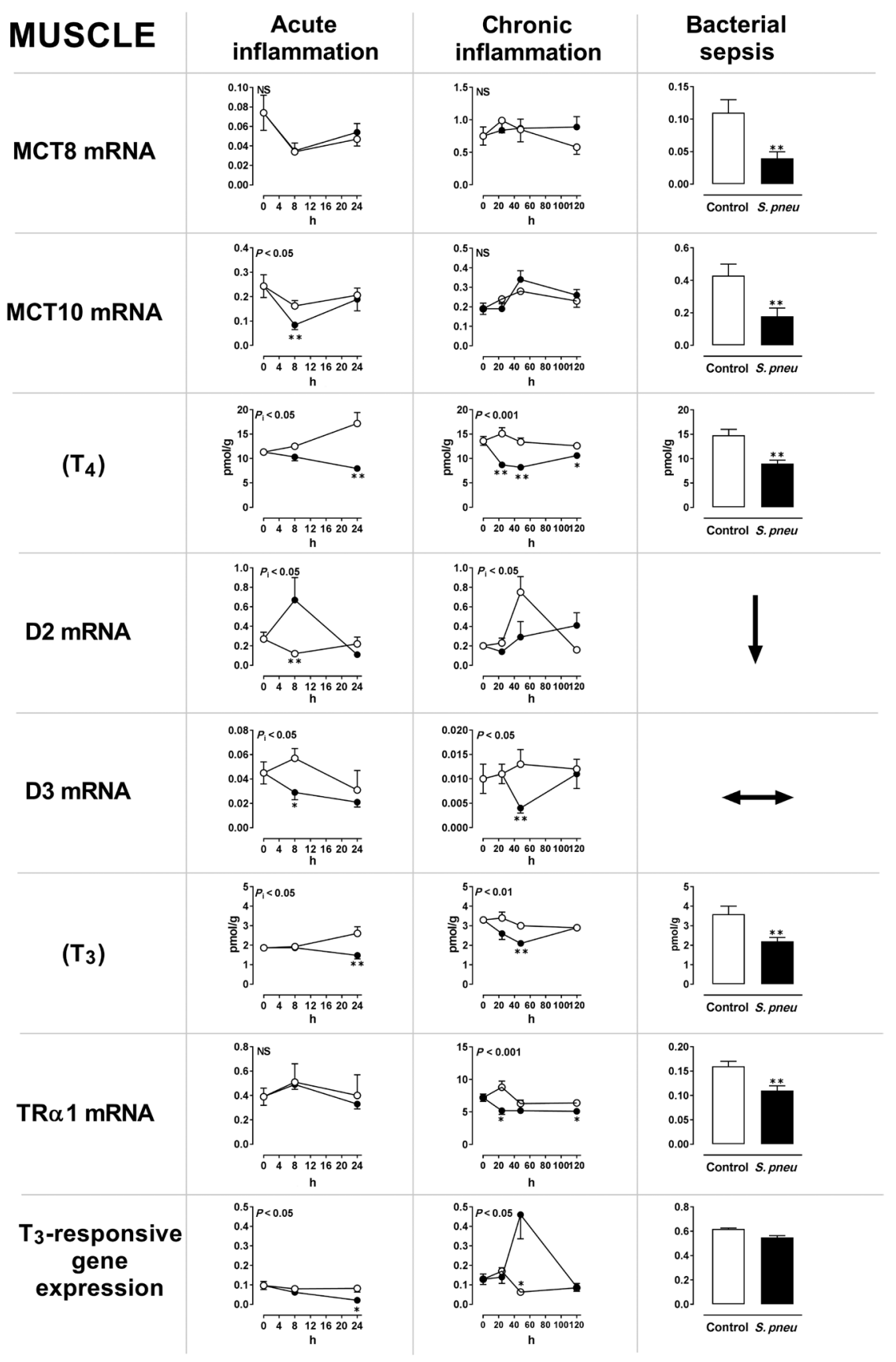

Figure 3

Relative expression of S/C16A2 (MCT8), SCl16A10 (MCT10), Dio2, Dio3, Thra1 and Myog mRNA and $\mathrm{T}_{3}$ and $\mathrm{T}_{4}$ concentrations in the skeletal muscle of mice during acute inflammation, chronic inflammation and bacterial sepsis compared to saline-treated controls. Dio2 and Dio3 mRNA expression during bacterial sepsis has been published previously (Kwakkel et al.); Dio2 decreases during bacterial sepsis, whereas Dio3 mRNA expression does not change. White bars and open circles represent saline-injected mice, black bars and filled circles represent treated mice. Mean values \pm S.E.M. are depicted. $P$ values indicate the effect of treatment as evaluated by a two-way ANOVA. Differences between groups ( $n=6$ mice per group) were analyzed post hoc with Tukey's test. ${ }^{*} P \leq 0.05, * * P \leq 0.01$. 


\section{Discussion}

It has been known for decades that illness decreases serum thyroid hormone concentrations, but the functional meaning of the observed changes in thyroid hormone concentrations, collectively known as the nonthyroidal illness syndrome (NTIS), remains incompletely understood. Although the prevailing view was that NTIS results in overall downregulation of metabolism to save energy, recent work has shown a more complex picture (Boelen et al. 2011). The present study aimed to evaluate the illness-induced alterations in liver and muscle thyroid hormone metabolism in mice using three different NTIS models that differ in timing and severity (acute inflammation, chronic inflammation and bacterial sepsis) in a systematic way. We are the first to measure liver and muscle tissue $\mathrm{TH}$ concentrations during NTIS in the same tissue and model at the same time point to establish the contribution of the tissue-specific changes in TH metabolism to the tissue TH concentrations.

Plasma $\mathrm{T}_{3}$ and $\mathrm{T}_{4}$ concentrations decreased during acute illness, chronic inflammation and lethal bacterial sepsis as observed previously (Boelen et al. 2004, 2005, 2008). The pathogenesis of the decrease in plasma $\mathrm{TH}$ concentrations is multifactorial; downregulation of the central part of the HPT axis, reduced production by the thyroid gland and diminished peripheral conversion in the liver (Boelen et al. 2011). Although all organs are exposed to similar circulating thyroid hormone concentrations, liver and muscle display a differential expression of deiodinating enzymes. Liver expresses D1 and D3, whereas muscle tissue expresses D2 and D3 implying a tissue specific modulation of local thyroid hormone signalling (Bianco \& Kim 2006).
To become available for the deiodinating enzymes, $\mathrm{T}_{4}$ must cross the plasma membrane. High-affinity transporter systems for both $\mathrm{T}_{4}$ and $\mathrm{T}_{3}$ have been identified, translocating the hormone across the plasma membrane. This transport is dependent on temperature, energy (ATP) and sodium and rate limiting for subsequent cellular thyroid hormone metabolism without affecting the deiodinating process or the binding of $\mathrm{T}_{3}$ to the receptor (Hennemann et al. 2001).

In the liver, NTIS is known to affect TH transport at the level of the plasma membrane. Decreased liver ATP and increased concentrations of compounds that inhibit $\mathrm{T}_{4}$ transport into the liver (bilirubin, non-esterified fatty acids) may contribute to reduced transport of $\mathrm{T}_{4}$ into the hepatocyte (Hennemann et al. 2001). Liver TH transporter expression itself is also affected during NTIS. Interestingly, changes in liver TH transporter expression appeared to differ between the NTIS models; acute illness lowers Slc16A2 and Slc16A10 expression, whereas chronic inflammation results in decreased Slc16A2 mRNA expression and an increase in Slc16A10 mRNA. Lethal bacterial sepsis affects hepatic $\mathrm{TH}$ transport only marginally. However, the (sometimes small) alterations in liver Slc16A2 and Slc16A10 mRNA expression observed in our study are not determinative in affecting liver $\mathrm{TH}$ concentrations as the alterations observed in plasma $\mathrm{TH}$ concentrations are more or less identical to the decrease observed in liver TH concentrations in all three models of NTIS (Fig. 4). This is associated with a marked reduction in $\mathrm{T}_{3}$ signalling represented by decreased liver Me1 mRNA expression.

Illness also differentially affects the expression and activity of liver D1 and D3; acute inflammation results in a marked decrease in both D1 and D3 activity, whereas chronic inflammation and bacterial sepsis downregulate

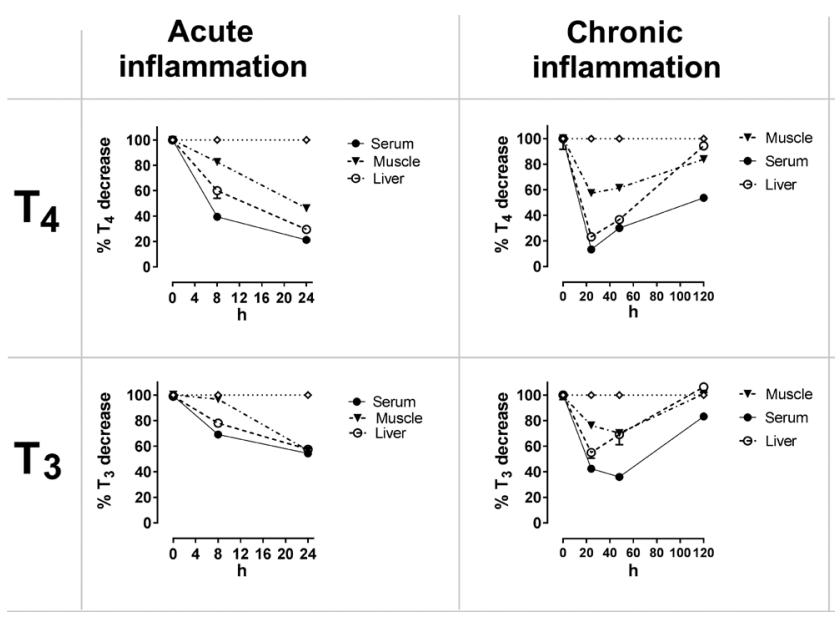

http://joe.endocrinology-journals.org DOI: $10.1530 / J O E-16-0483$ (c) 2017 Society for Endocrinology Printed in Great Britain

\section{Bacterial \\ sepsis}
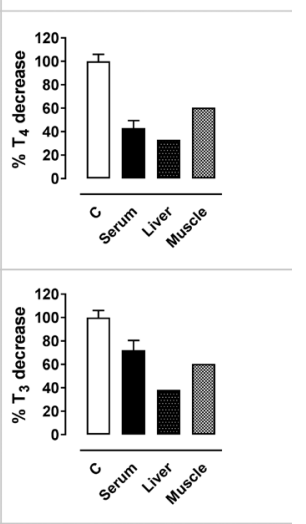

Figure 4

Relative decreases in serum, liver and muscle $\mathrm{T}_{4}$ and $\mathrm{T}_{3}$ concentrations during acute inflammation, chronic inflammation and bacterial sepsis compared to saline-treated controls, which were set at $100 \%$ at each time point. 
liver D3 activity. Liver D1 activity is only marginally affected. Studies in euthyroid mice have shown that D1 is not essential for $\mathrm{TH}$ action and should be primarily considered as a scavenger enzyme that deiodinates sulphated TH. Furthermore, as a $\mathrm{T}_{3}$-responsive gene, D1 plays a role in decreasing the amount of circulating thyroid hormones during hyperthyroidism (Mullur et al. 2014). We showed in TR $\beta$ KO mice, which have almost undetectable D1 activity in the liver that the LPS-induced decrease in plasma $\mathrm{TH}$ concentrations is similar in $\mathrm{KO}$ and WT, suggesting that D1 does not play an important role in lowering plasma and liver $\mathrm{TH}$ concentrations during illness (Kwakkel et al. 2008).

Illness-induced reduced liver D3 activity has been observed previously in mice (Boelen et al. 2005, 2008), whereas liver D3 increases in human liver during prolonged critical illness (Peeters et al. 2003). A rabbit model for prolonged critical illness developed by van den Berghe and coworkers showed clinical, biochemical and endocrine features similar to those seen in ICU patients (Debaveye et al. 2005, Weekers et al. 2003) and liver D3 activity tends to increase in these animals (Debaveye et al. 2008). The response of D3 to inflammation/illness might be dependent on the energy status; we showed that longterm fasting results in increased liver D3 expression and activity in rodents (Boelen et al. 2012, de Vries et al. 2015), and prolonged illness is associated with diminished food intake (Langouche et al. 2013). Theoretically, the decrease in D3 might prevent/ameliorate the illnessinduced decrease in liver $\mathrm{T}_{3}$ concentrations. However, the relatively low D3 activity levels present in the control animals are difficult to reconcile with a robust adaptation mechanism.

In humans, most of circulating $\mathrm{T}_{3}(80 \%)$ is produced via peripheral conversion by $\mathrm{D} 1$ (liver and kidney) and D2 (skeletal muscle) (Maia et al. 2005). In rodents, approximately $50 \%$ of circulating $\mathrm{T}_{3}$ is produced outside the thyroid. It has been shown in rats that the amount of nuclear-bound $\mathrm{T}_{3}$ derived from plasma $\mathrm{T}_{3}$ or from local production differs between tissues. Local conversion of $\mathrm{T}_{4}$ contributes $80 \%$ of the nuclear-bound $\mathrm{T}_{3}$ in the cerebral cortex, $40 \%$ in muscle and only $5 \%$ in liver (Hennemann et al. 2001). The liver can therefore be seen as a tissue that rapidly equilibrates with plasma concentrations. Our results suggest that also during illness plasma $\mathrm{TH}$ concentrations are the major determinant for liver TH concentrations in mice (Fig. 4), despite the illness-induced alterations in liver Mct8, Mct10, D1 and D3. Reduced liver TH concentrations have also been described in NTIS patients (Arem et al. 1993) and critically ill rabbits (Debaveye et al. 2008).

To evaluate muscle thyroid hormone metabolism during illness, we measured TH transporters, Dio2 and Dio3 mRNA expression, Thra1 mRNA expression and muscle $\mathrm{T}_{3}$ and $\mathrm{T}_{4}$ concentrations in acute inflammation, chronic inflammation and bacterial sepsis. We also determined muscle myogenin (Myog) mRNA expression, a $T_{3}$-target gene as a representative reflection of $\mathrm{TH}$ action. TH concentrations were measured in muscle tissue using a previously published protocol with minor modifications (Ackermans et al. 2011). To prevent coagulation of the muscle fibres, we introduced an additional homogenisation step using small amounts of PBS before the homogenisation step with $\mathrm{MeOH}$. The adapted protocol allows us to measure $\mathrm{TH}$ concentrations in very small amounts $\left(20-30 \mathrm{mg}\right.$ ) of muscle tissue. Muscle $\mathrm{T}_{3}$ levels in control mice are around $3 \mathrm{pmol} / \mathrm{g}$ muscle tissue, slightly lower than those in liver. Muscle $\mathrm{T}_{4}$ concentrations are approximately $15 \mathrm{pmol} / \mathrm{g}$ muscle tissue, more than $60 \%$ lower than those in liver $\mathrm{T}_{4}$ concentrations, which is in agreement with the fact that the local conversion of $\mathrm{T}_{4}$ contributes significantly to muscle $\mathrm{T}_{3}$ concentrations (Gereben et al. 2008).

We observed that muscle $\mathrm{TH}$ metabolism is differentially affected during illness. Acute inflammation and bacterial sepsis lowered TH transport into the cell, whereas chronic inflammation did not result in altered transporter expression. Muscle Dio2 expression increases whereas Dio3 expression decreases during acute illness as observed before (Kwakkel et al. 2010). In contrast, bacterial sepsis lowers muscle Dio2 expression (Kwakkel et al. 2009). In D2-expressing cells such as muscle cells, most of the nuclear-bound $\mathrm{T}_{3}$ is derived from intracellular conversion of $\mathrm{T}_{4}$ into $\mathrm{T}_{3}$ by $\mathrm{D} 2$ (Arrojo \& Bianco 2011). D2 is the dominant deiodinase in muscle tissue and is thought to play an important role in local TH metabolism and muscle function. This is in agreement with the observation that the global D2KO mice display a severely hypothyroid muscle phenotype despite normal serum $\mathrm{T}_{3}$ concentrations (Galton et al. 2009). Furthermore, it has been shown that tight regulation of intracellular TH levels in muscle stem cells (MSC) is essential for muscle development and function (Dentice et al. 2010). However, an elegant study by the Bianco group using mice with skeletal musclespecific D2 knockdown showed that these mice display normal muscle fibre characteristics and only mild signs of muscle hypothyroidism, implying that thyroid hormone (c) 2017 Society for Endocrinology Printed in Great Britain
Published by Bioscientifica Ltd 
signalling in muscle fibres is independent of D2 in adult muscle cells (Werneck-de-Castro et al. 2015).

Interestingly, despite variable alterations in transporter expression and deiodinating enzymes during acute, chronic inflammation and bacterial sepsis, muscle $\mathrm{T}_{3}$ and $\mathrm{T}_{4}$ concentrations were lower in all NTIS models compared to those in controls. This is partly in agreement with reduced Myog mRNA expression observed during acute inflammation. However, $\mathrm{T}_{3}$-responsive gene expression was not decreased in muscle during chronic inflammation and bacterial sepsis, which suggests that $\mathrm{TH}$ action in muscle is not solely dependent on muscle $T_{3}$ concentrations. This is in agreement with the observation that Dio2 knockdown in myocytes does not affect $\mathrm{T}_{3}$-responsive gene expression in muscle to a large extent questioning the potential importance of myocytespecific $\mathrm{T}_{3}$ production (Werneck-de-Castro et al. 2015). Our experimental setting does not allow us to exclude the possibility that inflammation by itself affects Myog expression. Inflammatory signals are able to affect Myog expression (Chen et al. 2007, Zhan et al. 2007). However, an in vivo model of muscle repair demonstrated reduced Myog expression in the muscle of D2KO mice but not in WT muscle, despite both genotypes displaying inflammatory cell infiltration (and thus a pro-inflammatory environment) (Dentice et al. 2010). We therefore consider inflammation less likely to be involved in the regulation of Myog expression in our experimental setting.

We recently published the effects of bacterial sepsis and chronic inflammation on the diaphragm, the main respiratory muscle containing type I, slow twitch, fibres, and type II, fast twitch, fibres (Bloise et al. 2016). In that study, we observed that sepsis resulted in increased Dio3 expression and decreased Dio2, which was associated with reduced $\mathrm{TH}$ signalling as the $\mathrm{T}_{3}$-regulated genes Tnni2 and Myog were decreased. Chronic inflammation on the other hand resulted in decreased Dio3 expression in the diaphragm (Bloise et al. 2016). Thus, the changes observed in skeletal muscle in the present study are similar to the changes observed earlier in the diaphragm during illness.

Several studies postulate that the illness-induced alterations depend on the severity and type of illness. We showed that indeed differences in illness severity and timing result in differential changes in transporters, deiodinases and TR expression in muscle and liver. We are the first to measure liver and muscle TH concentrations also in addition to the genes involved in local $\mathrm{TH}$ metabolism. Interestingly, illness results in decreased tissue $\mathrm{TH}$ concentrations in addition to low serum $\mathrm{TH}$ concentrations, regardless of the type of inflammation.
The illness-induced TH decrease is more severe in liver, however, is also present in skeletal muscle confirming the fact that almost half of the muscle TH concentrations is derived from local conversion. The (relatively small) decrease in muscle TH levels is partly associated with minor changes in $T_{3}$-responsive gene expression suggesting that muscle tissue is less vulnerable to illnessinduced changes in thyroid hormone metabolism by maintaining $\mathrm{TH}$ action at an appropriate level especially during the chronic phase of illness. Additional studies with cell-specific knockout models will be necessary to unravel the increasingly complex mechanisms involved in the pathogenesis of NTIS.

\section{Declaration of interest}

The authors declare that there is no conflict of interest that could be perceived as prejudicing the impartiality of the research reported.

\section{Funding}

This research did not receive any specific grant from any funding agency in the public, commercial or not-for-profit sector.

\section{Acknowledgements}

The authors would like to thank the staff of the Laboratory of Endocrinology for measuring serum thyroid hormones.

\section{References}

Ackermans MT, Kettelarij-Haas Y, Boelen A \& Endert E 2011 Determination of thyroid hormones and their metabolites in tissue using SPE UPLC-tandem MS. Biomedical Chromatography 26 485-490. (doi:10.1002/bmc.1691)

Alkemade A, Friesema EC, Unmehopa UA, Fabriek BO, Kuiper GG, Leonard JL, Wiersinga WM, Swaab DF, Visser TJ \& Fliers E 2005 Neuroanatomical pathways for thyroid hormone feedback in the human hypothalamus. Journal of Clinical Endocrinology and Metabolism 90 4322-4334. (doi:10.1210/jc.2004-2567)

Arem R, Wiener GJ, Kaplan SG, Kim HS, Reichlin S \& Kaplan MM 1993 Reduced tissue thyroid hormone levels in fatal illness. Metabolism 42 1102-1108. (doi:10.1016/0026-0495(93)90266-Q)

Arrojo EDR \& Bianco AC 2011 Type 2 deiodinase at the crossroads of thyroid hormone action. International Journal of Biochemistry and Cell Biology 43 1432-1441. (doi:10.1016/j.biocel.2011.05.016)

Bassett JH, Harvey CB \& Williams GR 2003 Mechanisms of thyroid hormone receptor-specific nuclear and extra nuclear actions. Molecular and Cellular Endocrinology 213 1-11. (doi:10.1016/j. mce.2003.10.033)

Bianco AC \& Kim BW 2006 Deiodinases: implications of the local control of thyroid hormone action. Journal of Clinical Investigation 116 2571-2579. (doi:10.1172/JCI29812)

Bloise FF, van der Spek AH, Surovtseva OV, Ortiga-Carvalho TM, Fliers E \& Boelen A 2016 Differential effects of sepsis and chronic inflammation on diaphragm muscle fiber type, thyroid hormone metabolism,

Published by Bioscientifica Ltd 
and mitochondrial function. Thyroid 26 600-609. (doi:10.1089/ thy.2015.0536)

Boelen A, Kwakkel J, Thijssen-Timmer DC, Alkemade A, Fliers E \& Wiersinga WM 2004 Simultaneous changes in central and peripheral components of the hypothalamus-pituitary-thyroid axis in lipopolysaccharide-induced acute illness in mice. Journal of Endocrinology 182 315-323. (doi:10.1677/joe.0.1820315)

Boelen A, Kwakkel J, Alkemade A, Renckens R, Kaptein E, Kuiper G, Wiersinga WM \& Visser TJ 2005 Induction of type 3 deiodinase activity in inflammatory cells of mice with chronic local inflammation. Endocrinology 146 5128-5134. (doi:10.1210/en.20050608)

Boelen A, Boorsma J, Kwakkel J, Wieland CW, Renckens R, Visser TJ, Fliers E \& Wiersinga WM 2008 Type 3 deiodinase is highly expressed in infiltrating neutrophilic granulocytes in response to acute bacterial infection. Thyroid 18 1095-1103. (doi:10.1089/thy.2008.0090)

Boelen A, Kwakkel J \& Fliers E 2011 Beyond low plasma T3: local thyroid hormone metabolism during inflammation and infection. Endocrine Reviews 32 670-693. (doi:10.1210/er.2011-0007)

Boelen A, van BM, Vos X, Surovtseva O, Belegri E, Saaltink DJ, Vreugdenhil E, Kalsbeek A, Kwakkel J \& Fliers E 2012 Leptin administration restores the fasting-induced increase of hepatic type 3 deiodinase expression in mice. Thyroid 22 192-199. (doi:10.1089/ thy.2011.0289)

Brent GA 2000 Tissue-specific actions of thyroid hormone: insights from animal models. Reviews in Endocrine and Metabolic Disorders $127-33$. (doi:10.1023/A:1010056202122)

Burmeister LA, Pachucki J \& St Germain DL 1997 Thyroid hormones inhibit type 2 iodothyronine deiodinase in the rat cerebral cortex by both pre- and posttranslational mechanisms. Endocrinology 138 5231-5237. (doi:10.1210/en.138.12.5231)

Chen SE, Jin B \& Li YP 2007 TNF-alpha regulates myogenesis and muscle regeneration by activating p38 MAPK. American Journal of Physiology: Cell Physiology 292 C1660-C1671. (doi:10.1152/ ajpcell.00486.2006)

de Vries EM, Eggels L, van Beeren HC, Ackermans MT, Kalsbeek A, Fliers E \& Boelen A 2014 Fasting-induced changes in hepatic thyroid hormone metabolism in male rats are independent of autonomic nervous input to the liver. Endocrinology 155 5033-5041. (doi:10.1210/en.2014-1608)

de Vries EM, van Beeren HC, Ackermans MT, Kalsbeek A, Fliers E \& Boelen A 2015 Differential effects of fasting vs food restriction on liver thyroid hormone metabolism in male rats. Journal of Endocrinology 224 25-35. (doi :10.1530/joe-14-0533)

Debaveye Y, Ellger B, Mebis L, Van HE, Coopmans W, Darras V \& Van den Berghe G 2005 Tissue deiodinase activity during prolonged critical illness: effects of exogenous thyrotropin-releasing hormone and its combination with growth hormone-releasing peptide-2. Endocrinology 146 5604-5611. (doi:10.1210/en.2005-0963)

Debaveye Y, Ellger B, Mebis L, Darras VM \& Van den Berghe G 2008 Regulation of tissue iodothyronine deiodinase activity in a model of prolonged critical illness. Thyroid 18 551-560. (doi:10.1089/ thy.2007.0287)

Dentice M, Marsili A, Ambrosio R, Guardiola O, Sibilio A, Paik JH, Minchiotti G, DePinho RA, Fenzi G, Larsen PR, et al. 2010 The FoxO3/type 2 deiodinase pathway is required for normal mouse myogenesis and muscle regeneration. Journal of Clinical Investigation 120 4021-4030. (doi:10.1172/JCI43670)

Galton VA, Schneider MJ, Clark AS \& St Germain DL 2009 Life without thyroxine to 3,5,3'-triiodothyronine conversion: studies in mice devoid of the 5'-deiodinases. Endocrinology 150 2957-2963. (doi:10.1210/en.2008-1572)

Gereben B, Zeold A, Dentice M, Salvatore D \& Bianco AC 2008 Activation and inactivation of thyroid hormone by deiodinases: local action with general consequences. Cellular and Molecular Life Sciences 65 570-590. (doi:10.1007/s00018-007-7396-0)
Hennemann G, Docter R, Friesema EC, de Jong M, Krenning EP \& Visser TJ 2001 Plasma membrane transport of thyroid hormones and its role in thyroid hormone metabolism and bioavailability. Endocrine Reviews 22 451-476. (doi:10.1210/edrv.22.4.0435)

Heuer H, Maier MK, Iden S, Mittag J, Friesema EC, Visser TJ \& Bauer K 2005 The monocarboxylate transporter 8 linked to human psychomotor retardation is highly expressed in thyroid hormonesensitive neuron populations. Endocrinology 146 1701-1706. (doi:10.1210/en.2004-1179)

Kohrle J 2000 The selenoenzyme family of deiodinase isozymes controls local thyroid hormone availability. Reviews in Endocrine and Metabolic Disorders 1 49-58. (doi:10.1023/A:1010012419869)

Kwakkel J, Chassande O, van Beeren HC, Wiersinga WM \& Boelen A 2008 Lacking thyroid hormone receptor beta gene does not influence alterations in peripheral thyroid hormone metabolism during acute illness. Journal of Endocrinology 197 151-158. (doi:10.1677/JOE-070601)

Kwakkel J, van Beeren HC, Ackermans MT, Platvoet-ter Schiphorst MC, Fliers E, Wiersinga WM \& Boelen A 2009 Skeletal muscle deiodinase type 2 regulation during illness in mice. Journal of Endocrinology 203 263-270. (doi:10.1677/JOE-09-0118)

Kwakkel J, Chassande O, van Beeren HC, Fliers E, Wiersinga WM \& Boelen A 2010 Thyroid hormone receptor \{alpha\} modulates lipopolysaccharide-induced changes in peripheral thyroid hormone metabolism. Endocrinology 151 1959-1969. (doi:10.1210/en.20091049)

Langouche L, Vander Perre S, Marques M, Boelen A, Wouters PJ, Casaer MP \& Van den Berghe G 2013 Impact of early nutrient restriction during critical illness on the nonthyroidal illness syndrome and its relation with outcome: a randomized, controlled clinical study. Journal of Clinical Endocrinology and Metabolism 98 1006-1013. (doi:10.1210/jc.2012-2809)

Maia AL, Kim BW, Huang SA, Harney JW \& Larsen PR 2005 Type 2 iodothyronine deiodinase is the major source of plasma T3 in euthyroid humans. Journal of Clinical Investigation 115 2524-2533. (doi:10.1172/JCI25083)

Mullur R, Liu YY \& Brent GA 2014 Thyroid hormone regulation of metabolism. Physiological Reviews 94 355-382. (doi:10.1152/ physrev.00030.2013)

Peeters RP, Wouters PJ, Kaptein E, Van Toor H, Visser TJ \& van den Berghe G 2003 Reduced activation and increased inactivation of thyroid hormone in tissues of critically ill patients. Journal of Clinical Endocrinology and Metabolism 88 3202-3211. (doi:10.1210/jc.2002022013)

Reyns GE, Janssens KA, Buyse J, Kuhn ER \& Darras VM 2002 Changes in thyroid hormone levels in chicken liver during fasting and refeeding. Comparative Biochemistry and Physiology Part B: Biochemistry and Molecular Biology 132 239-245. (doi:10.1016/S1096-4959(01)00528-0)

Ruijter JM, Ramakers C, Hoogaars WM, Karlen Y, Bakker O, van den Hoff MJ \& Moorman AF 2009 Amplification efficiency: linking baseline and bias in the analysis of quantitative PCR data. Nucleic Acids Research 37 e45. (doi:10.1093/nar/gkp045)

Sjogren M, Alkemade A, Mittag J, Nordstrom K, Katz A, Rozell B, Westerblad H, Arner A \& Vennstrom B 2007 Hypermetabolism in mice caused by the central action of an unliganded thyroid hormone receptor alpha1. EMBO Journal 26 4535-4545. (doi:10.1038/ sj.emboj.7601882)

van Zeijl CJ, Surovtseva OV, Kwakkel J, van Beeren HC, Bassett JH, Williams GR, Wiersinga WM, Fliers E \& Boelen A 2014 Thyrostimulin deficiency does not alter peripheral responses to acute inflammationinduced nonthyroidal illness. American Journal of Physiology: Endocrinology and Metabolism 307 E527-E537. (doi :10.1152/ ajpendo.00266.2014)

Visser WE, Friesema EC \& Visser TJ 2011 Minireview: thyroid hormone transporters: the knowns and the unknowns. Molecular Endocrinology 25 1-14. (doi:10.1210/me.2010-0095) 
Weekers F, Giulietti AP, Michalaki M, Coopmans W, Van HE, Mathieu C \& Van den Berghe G 2003 Metabolic, endocrine, and immune effects of stress hyperglycemia in a rabbit model of prolonged critical illness. Endocrinology 144 5329-5338. (doi:10.1210/en.2003-0697)

Werneck-de-Castro JP, Fonseca TL, Ignacio DL, Fernandes GW, Andrade-Feraud CM, Lartey LJ, Ribeiro MB, Ribeiro MO, Gereben B \& Bianco AC 2015 Thyroid hormone signaling in male mouse skeletal muscle is largely independent of D2 in myocytes. Endocrinology 156 3842-3852. (doi:10.1210/en.2015-1246)
Wiersinga WM \& Chopra IJ 1982 Radioimmunoassay of thyroxine (T4), 3,5,3'-triiodothyronine (T3), 3,3',5'-triiodothyronine (reverse T3, rT3), and 3,3'-diiodothyronine (T2).

Methods in Enzymology 84 272-303. (doi :10.1016/00766879(82)84024-x)

Zhan M, Jin B, Chen SE, Reecy JM \& Li YP 2007 TACE release of TNF-alpha mediates mechanotransduction-induced activation of p38 MAPK and myogenesis. Journal of Cell Science 120 692-701. (doi:10.1242/jcs.03372)

Received in final form 23 December 2016

Accepted 27 January 2017

Accepted Preprint published online 27 January 2017
Published by Bioscientifica Ltd. 